\title{
PENGARUH UKURAN PERUSAHAAN DAN LIKUIDITAS TERHADAP STRUKTUR MODAL (STUDI PADA PERUSAHAAN MANUFAKTUR SEKTOR MAKANAN DAN MINUMAN DI BURSA EFEK INDONESIA)
}

\author{
Chaerunnisa Rumianti*) \\ STIEM BONGAYA MAKASSAR; JL. Letjen Pol A. Mappaoddang No. 28, Telp 0411.873.797 \\ Jurusan Manajemen, STIEM Bongaya Makassar \\ E-mail: tataabiyy@gmail.com
}

\begin{abstract}
Abstrak
Penelitian ini bertujuan untuk menguji dan menganalisis Pengaruh Ukuran Perusahaan dan Likuiditas Terhadap Struktur Modal (Studi Pada Perusahaan Manufaktur Sektor Makanan Dan Minuman Di Bursa Efek Indonesia). Pengumpulan data menggunakan data sekunder. Populasi dalam penelitian ini adalah laporan keuangan seluruh perusahaan yang termasuk dalam sektor manufaktur industri makanan dan minuman yang terdaftar pada Bursa Efek Indonesia dari tahun 2014-2016 yang di ambil dengan metode purposive sampling, ada 42 sampel dari laporan keuangan Perusahaan Manufaktur Sektor Makanan Dan Minuman Di Bursa Efek Indonesia. Hasil laporan keuangan telah diuji asumsi klasik berupa asumsi normalitas, heteroskedastisitas dan multikolonieritas. Metode analisis data menggunakan teknik regresi berganda. Hasil penelitian menunjukkan berdasarkan uji t variabel ukuran perusahaan tidak berpengaruh dan tidak signifikan terhadap struktur modal dan variabel likuiditas berpengaruh positif dan signifikan terhadap struktur modal. Secara uji F (simultan) ukuran perusahaan dan likuiditas berpengaruh positif dan signifikan terhadap struktur modal (Studi Pada Perusahaan Manufaktur Sektor Makanan Dan Minuman Di Bursa Efek Indonesia).
\end{abstract}

Kata kunci: Ukuran Perusahaan, Likuiditas, Struktur Modal

\begin{abstract}
This study aims to test and analyse the Company Size and Liquidity Influence the Capital Structure (Studies in Manufacturing Companies in the Food and Beverage Sector in the Indonesia Stock Exchange). Data collection uses secondary data. The population in this study is the financial statements of all companies included in the food and beverage manufacturing sector listed on the Indonesia Stock Exchange from 2014-2016 taken by purposive sampling method, there are 42 samples from the financial statements of the Manufacturing Company in the Food and Beverage Sector in the Indonesia Stock Exchange. The financial statements have been tested for classic assumptions in the form of assumptions of normality, heteroscedasticity and multicolonality. Data analysis method uses multiple regression techniques. The results showed that based on the t-test, the variable of firm size has no effect and insignificant effect on the capital structure and the variable liquidity had a positive and significant effect on the capital structure. In the F test (simultaneous) the size of the company and liquidity have a positive and significant effect on the capital structure (Study in Manufacturing Companies in the Food and Beverage Sector in the Indonesia Stock Exchange).
\end{abstract}

Keywords: Company Size, Liquidity, Capital Structure

\section{PENDAHULUAN}

Salah satu keputusan penting yang dihadapi manajer keuangan dalam kaitannya dengan kegiatan operasi penusahaan adalah keputusan pendanaan. Dimana keputusan pendanaan yang baik dilihat dari struktur modal. Seiring majunya perkembangan teknologi, industri manufaktur juga dituntut 
untuk lebih berkompetitif dan terus berinovasi dalam menciptakan suatu produk yang berkualitas tinggi serta mampu bersaing secara global dan mampu mencukupi permintaan konsumen akan produk yang terus bertambah. Masalah struktur modal merupakan masalah yang penting bagi setiap perusahaan, karena tinggi rendahnya struktur modal akan mencerminkan posisi keuangan suatu perusahaan. Sehingga perusahaan dituntut untuk mampu menciptakan struktur modal yang optimal dengan cara menghimpun dana baik dari dalam maupun luar perusahaan. Pihak manajemen harus mempertimbangkan baik buruknya keputusan pendanaan apakah perusahaan menggunakan modal asing (hutang) ataukah modal sendiri (modal saham, laba ditahan, dan cadangan), dimana kedua pilihan tersebut memiliki kelebihan dan risiko masing-masing. Perusahaan yang menggunakan dana dari pihak luar harus memiliki sikap kehati-hatian karena memiliki risiko hutang yaitu perusahaan harus membayar beban bunga. Beban bunga yang terlalu besar akan mengurangi laba operasi yang ada didalam perusahaan sehingga akan mengakibatkan penurunan laba bersih. Perusahaan yang memilih modal sendiripun memiliki kendala yaitu dana yang tersedia untuk usaha terbatas sehingga berdampak pada hasil yang diperoleh juga terbatas. Keuntungan perusahaanketika meminjam pihak luar atau menggunakan hutang yaitu tidak harus membayar pajak dari penghematan pajak inilah profit yang diperoleh perusahaan akan lebih besar dibandingkan dengan perusahaan yang tidak menggunakan hutang.

Bagi perusahaan yang mencari keuntungan biasanya mengutamakan keuntungan bagi pemiliknya atau pemegang saham. Pemegang saham dengan membeli saham berarti mengharapkan return tertentu dengan risiko minimal. Dengan tingginya tingkat return yang diperoleh pemegang saham maka para pemegang saham akan tertarik dan harga saham semakin tinggi, sehingga kesejahteraan pemegang saham akan meningkat. Disamping itu juga bertujuan untuk mempertahankan kelangsungan hidup perusahaan dan melakukan pengembangan usahanya. Adanya faktor-faktor yang mempengaruhi DER perusahaan menjadi hal yang penting sebagai dasar pertimbangan dalam menentukan komposisi struktur modal perusahaan. Faktor-faktor yang dapat mempengaruhi komposisi struktur modal perusahaan diantaranya stabilitas penjualan, struktur aktiva, leverage operasi, tingkat pertumbuhan, profitabilitas, pajak, pengendalian, sikap manajemen, ukuran perusahaan, dan fleksibilitas keuangan. Dalam penelitian ini, peneliti hanya membatasi beberapa faktor yang akan diteliti yang diduga berpengaruh terhadap DER diantaranya ukuran perusahaan, dan likuiditas.

Ukuran perusahaan adalah salah satu faktor yang digunakan perusahaan untuk menentukan berapa besar kebijakan struktur modal dalam memenuhi besar aset suatu perusahaan. Apabila perusahaan semakin besar maka semakin besar pula dana yang akan dikeluarkan, baik itu dari kebijakan hutang atau modal sendiri dalam mempertahankan atau mengembangkan perusahaan. Ukuran perusahaan menggambarkan besar kecilnya perusahaan. Besar kecilnya usaha tersebut ditinjau dari lapangan usaha yang dijalankan. Penentuan skala besar kecilnya perusahaan dapat ditentukan berdasarkan total penjualan, total asset, rata-rata tingkat penjualan (Seftianne, 2011).

Perusahaan yang berukuran besar mempunyai berbagai kelebihan dibanding perusahaan berukuran kecil. Kelebihan tersebut yang pertama adalah ukuran perusahaan dapat menentukan tingkat 
kemudahan perusahaan memperoleh dana dari pasar modal. Kedua, ukuran perusahaan menentukan kekuatan tawarmenawar (bargaining power) dalam kontrak keuangan. Dan ketiga, ada kemungkinan pengaruh skala dalam biaya dan return membuat perusahaan yang lebih besar dapat memperoleh lebih banyak laba (Sawir,2004).

Syafrida Hani (2015:121), pengertian likuiditas adalah kemampuan suatu perusahaan dalam memenuhi semua kewajiban keuangan yang segera dapat dicairkan atau yang sudah jatuh tempo. Menurut Pecking Order Theory, perusahaan dengan tingkat likuiditas yang tinggi biasanya tidak menggunakan pembiayaan dari hutang. Hal ini dikarenakan perusahaan dengan tingkat likuiditas tinggi memiliki dana internal yang besar sehingga perusahaan tersebut akan lebih memilih menggunakan dana internalnya terlebih dahulu untuk membiayai investasinya sebelum menggunakan pembiayaan eksternal (hutang). Dalam penelitian Ozkan (2001) dalam Kusumawati (2004), perusahaan dengan aset likuid yang besar dapat menggunakan aset ini untuk berinvestasi (pecking order theory). Likuiditas perusahaan adalah kekuatan perusahaan dalam melunasi kewajibannya yang jatuh tempo dalam jangka waktu pendek. Jika perusahaan banyak menggunakan aktiva lancar berarti perusahaan tersebut dapat menghasilkan aliran kas untuk membiayai aktivitas operasi dan investasi perusahaan. Aktiva lancar yang semakin besar menunjukan bahwa perusahaan berhasil melunasi hutang jangka pendeknya, sehingga hutang jangka pendek berkurang dan berakibat menurunnya proporsi hutang dalam struktur modal (Furi Vina Ratna dan Saifudin (2012).

Struktur modal menurut Sudana (2011:143) didefinisikan sebagai berikut: "Struktur modal (capital structure) berkaitan dengan pembelanjaan jangka panjang suatu perusahaan yang diukur dengan perbandingan utang jangka panjang dengan modal sendiri."Jadi struktur modal merupakan perbandingan antar utang jangka panjang dengan modal sendiri yang digunakan untuk pembelanjaan perusahaan.

Penelitian yang dilakukan oleh Luthfillah Zul Fahmi dan Kurnia (2017) dengan judul Pengaruh Struktur Aktiva, Ukuran Perusahaan dan Likuiditas terhadap Struktur Modal, menjelaskan bahwa -Ukuran Perusahaan berpengaruh signifikan dan positif terhadap struktur modal. Dan Likuiditas berpengaruh signifikan dan positif terhadap struktur modal dan penelitian yang di lakukan oleh Stenyverens, J.D Lasut., Paulina, Van Rate., dan Michael, Ch. Raintung. (2018) dengan judul Pengaruh ukuran perusahaan, profitabilitas dan likuiditas terhadap struktur modal pada perusahaan makanan dan minuman yang terdaftar di Bursa Efek Indonesia menjelaskan bahwa Ukuran Perusahaan memiliki pengaruh positif dan signifikan terhadap struktur modal. Dan Likuiditas berpengaruh negatif dan signifikan terhadap struktur modal.

\section{Rumusan Masalah}

Berdasarkan latar belakang yang telah dikemukakan sebelumnya, maka penulis menumuskan masalahnya sebagai berikut:

1. Apakah ukuran perusahaan berpengaruh terhadap Struktur Modal (Studi pada Perusahaan Manufaktur sektor Makanan dan Minuman yang Terdaftar di BEI) ?

2. Apakah likuiditas berpengaruh terhadap Struktur Modal (Studi pada Perusahaan Manufaktur sektor Makanan dan Minuman yang Terdaftar di BEI)?

3. Apakah ukuran perusahaan dan likuiditas secara simultan berpengaruh 
terhadap struktur modal (Studi pada Penusahaan Manufaktur Sektor Makanan dan Minuman yang terdaftar di BEI)?

\section{Tujuan Penelitian}

Berdasarkan rumusan masalah penelitiannya, maka tujuan dari penelitian ini adalah:

1. Untuk menguji dan menganalisis pengaruh ukuran perusahaan terhadap Struktur Modal (Studi pada Perusahaan Manufaktur sektor Makanan dan Minuman yang Terdaftar di BEI).

2. Untuk menguji dan menganalisis pengaruh likuiditas terhadap Struktur Modal (Studi pada Perusahaan Manufaktur sektor Makanan dan Minuman yang Terdaftar di BEI).

3. Untuk menguji dan menganalisis pengaruh ukuran perusahaan dan likuiditas secara simultan terhadap struktur modal (Studi pada Perusahaan Manufaktur Sektor Makanan dan Minuman yang terdaftar di BEI)?

\section{Gambar 1. Kerangka Konseptual Penelitian}

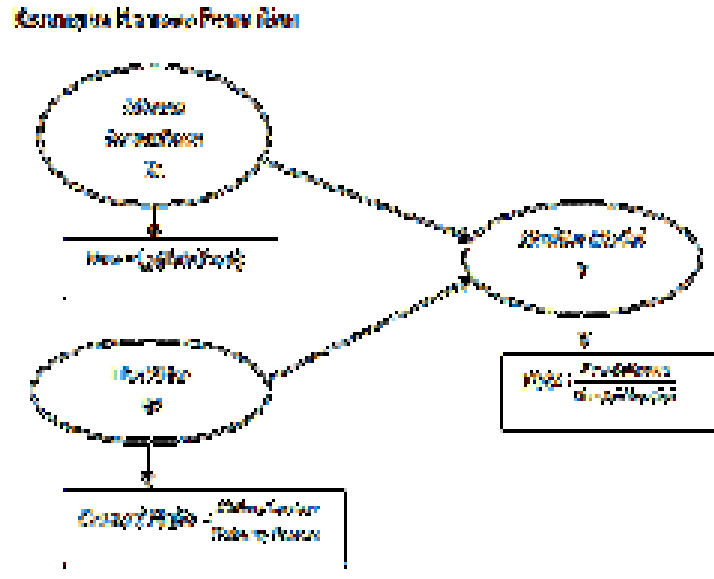

\section{Hipotesis}

Berdasarkan permasalahan dan tujuan penelitian maka hipotesis penelitian ini sebagai berikut :

1. Ukuran perusahaan berpengaruh positif dan signifikan terhadap Struktur Modal pada perusahaan manufaktur sektor makanan dan minuman di Bursa Efek Indonesia.

2. Likuiditas berpengaruh positif dan signifikan terhadap Struktur Modal pada perusahan manufaktur sektor makanan dan minuman di Bursa EfekIndonesia.

3. Ukuran perusahaan dan likuiditas secara simultan berpengaruh positif dan signifikan terhadap Struktur Modal pada perusahaan manufaktur sektor makanan dan minuman di Bursa Efek Indonesia.

\section{METODE PENELITIAN}

Dalam penelitian ini, pendekatan yang digunakan adalah pendekatan kuantitatif. Waktu yang diperlukan dalam mengumpulkan data sebagai sumber informasi dalam studi ini selama 2 bulan. Populasi dalam penelitian ini adalah seluruh perusahaan yang termasuk dalam sektor manufaktur industri makanan dan minuman yang terdaftar pada Bursa Efek Indonesia dari tahun 2014-2016. Perusahaan Manufaktur sektor Makanan dan Minuman yang terdaftar di Bursa Efek Indonesia sebanyak 18 perusahaan. Bentuk Pengumpulan Data yang digunakan adalah Data cross section dan Data berkala (time series data). Jenis data yang digunakan yakni data kualitatif dan kuantitatif. Sumber Data yang digunakan adalah data sekunder (secondary data) Teknik pengumpulan data dilakukan untuk mengumpulkan data dengan teknik dokumentasi berupa laporan keuangan (financial statements), laporan tahunan (annual report) dan/atau Publikasi Ringkasan Kinerja Perusahaan Tercatat manufaktur subsektor makanan dan minuman yang dipublikasi pada website BEI.

\section{METODE ANALISIS}

Analisis yang digunakan dalam penelitian ini adalah analisis deskriftif 
dan analisis inferensial dengan menggunakan Regresi Linear Berganda. Adapun persamaan dari regresi berganda dalam penelitian ini adalah sebagai berikut:

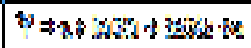

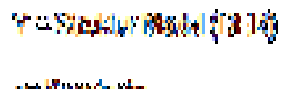

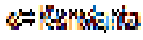

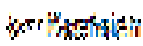

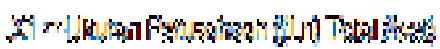

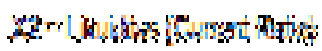

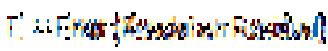

\section{HASIL PENELITIAN DAN \\ PEMBAHASAN}

Penelitian ini menggunakan data laporan keuangan perusahaan makanan dan minuman yang terdaftar di Bursa Efek Indonesia selama 3 (dua) tahun yaitu periode 2014-2016. Pengambilan sampel dilakukan dengan menggunakan teknik purposive sampling yaitu pengambilan sampel dengan kriteria tertentu seperti, perusahaan makanan dan minuman yang sudah bergabung di BEI selama 3 tahun berturut-turut (konstan) mulai dari periode 2014-2016, perusahaan tersebut secara periodik mengeluarkan laporan keuangan tiap tahunnya selama periode pengamatan, dan perusahaan yang memiliki kelengkapan data keuangan untuk menghitung rasio keuangan, seperti ukuran perusahaan, likuditas, dan struktur modal. Berdasarkan kriteria tersebut diperoleh sampel sebanyak 42 selama periode 2014-2016.

Adapun data perusahaan berdasarkan variabel yang ada dalam penelitian adalah sebagai berikut:

\section{a. Ukuran Perusahaan}

Ukuran Perusahaan untuk setiap perusahaan makanan dan minuman periode 2014-2016 dapat dilihat pada tabel berikut ini:
Tabel 1. Ukuran Perusahaan pada Perusahaan Makanan dan Minuman (Rasio)

\begin{tabular}{|c|c|c|c|c|}
\hline \multirow{2}{*}{ Nw } & \multirow{2}{*}{ Kut } & \multicolumn{3}{|c|}{ 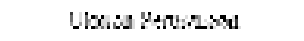 } \\
\hline & & 511 & $26: 2$ & $2 ! 16$ \\
\hline 1 & aflot & 1)? & $1+01$ & lo $\infty$ \\
\hline 2 & 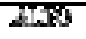 & $: 1 \% 2$ & 1900 & 12.00 \\
\hline$\overline{2}$ & ERES & Lis & $\mid x, 1$ & $74.9 \%$ \\
\hline$i$ & [E]A & $4: 8$ & $1>5 \%$ & $1 ? \%$ \\
\hline 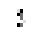 & axas & Thlle & 28,0 & $1: 1 ;$ \\
\hline $\bar{i}$ & Mta & $9 x$ & in, $;$ & 135 \\
\hline 7 & stiet & $+h$ & 10,95 & 1.435 \\
\hline 8 & akevise & 6.14 & ic,34 & $16 \leqslant 8$ \\
\hline 0 & Nast & 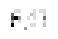 & $2 \&$ & $\therefore i 2$ \\
\hline 10 & eril & $\because \because$ & 1.31 & 1 \\
\hline 1. & $8 \mathrm{xh}$ & $i=1$ & $6 / 3$ & 13.5 \\
\hline $1 !$ & 207 & $y_{0}$ & 1.48 & 8,4 \\
\hline 13 & rise? & $\because 31$ & $2 \cdot 18$ & $11,6:$ \\
\hline 1: & X.า. & +9 & $19,0 ?$ & $1: 8$ \\
\hline
\end{tabular}

\section{b. Likuiditas}

Likuiditas untuk setiap perusahaan makanan dan minuman periode 20142016 dapat dilihat pada tabel berikut ini:

Tabel 2. Likuiditas pada Perusahaan Makanan dan Minuman (Rasio)

\begin{tabular}{|c|c|c|c|c|}
\hline \multirow{3}{*}{ EL } & \multirow{3}{*}{$\begin{array}{l}\text { Kalk } \\
\text { Alfte }\end{array}$} & \multicolumn{3}{|c|}{ 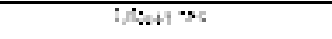 } \\
\hline & & ו ו & x/1 & ine \\
\hline & & $2 \alpha$ & 1.62 & $2: 2$ \\
\hline 6 & Alrog & 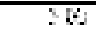 & $1: y$ & 60 \\
\hline$\because$ & WEAt & 142 & 150 & 2,18 \\
\hline 4 & Toch & $44 ?$ & $642^{2}$ & $2 / 4$ \\
\hline 5 & 7002 & $21 \%$ & 25 & $2 \times 1$ \\
\hline th & INDE & 1.1 & 13 & $1>1$ \\
\hline$\%$ & POAEI: & $9: 1$ & 252 & 25 \\
\hline 6 & BOP: & $2 \%$ & 237 & 23 \\
\hline$y$ & ases & 1 in & 1.1 & $1 \mathrm{Na}$ \\
\hline$\therefore$ & Eexi & $1.2 ?$ & 203 & $2 S:$ \\
\hline$T$ & Sxury & 155 & 3.15 & 3 \\
\hline 2 & TSE: & 119 & in & 3.22 \\
\hline .9 & $\operatorname{2ta}$ & 1.22 & $1 .: 2$ & 1.55 \\
\hline 2 & Dar? & 220 & 2.73 & 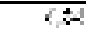 \\
\hline
\end{tabular}

\section{c. Struktur Modal}

Struktur Modal untuk setiap perusahaan makanan dan minuman periode 2014-2016 dapat dilihat pada tabel berikut ini: 
Tabel 3. Struktur Modal pada Perusahaan Makanan dan Minuman (Rasio)

\begin{tabular}{|c|c|c|c|c|}
\hline \multirow{2}{*}{$N_{0}$} & \multirow{2}{*}{ Kode } & \multicolumn{3}{|c|}{ Strukhu Matulil } \\
\hline & & 314 & M:1 & 314 \\
\hline . & ALSA & 108 & $1 \%$ & 1,1 \\
\hline 2 & NTO & 1,44 & 13 & $14:$ \\
\hline 2 & CIXA & 1,49 & $1 \%$ & 0,61 \\
\hline 4 & $18|T| A$ & 01 & 0,12 & 0,18 \\
\hline : & $|c| s \mid$ & $0,5 S$ & 0,02 & 0,9 \\
\hline 6 & $\mathrm{IN} \mid \mathrm{H}$ & 1,08 & 1,13 & 0,57 \\
\hline$i$ & MIII & 404 & $1: 4$ & 1,14 \\
\hline 8 & MYOR & 1,31 & 118 & $1,0,0$ \\
\hline 9 & PEDN & 0,4 & 181 & 1,4 \\
\hline 90 & ROII & 121 & 1,28 & 1,02 \\
\hline 11 & SKRW & 1,91 & 1,22 & 1,72 \\
\hline $1 !$ & SKKIT & 1,16 & 1,10 & 0,92 \\
\hline 12 & SITP & 105 & 181 & 1 \\
\hline .1 & ULT: & 029 & 0,27 & 021 \\
\hline
\end{tabular}

\section{PEMBAHASAN}

Dalam rangka menguji pengaruh ukuran perusahaan dan likuiditas terhadap struktur modal. Maka digunakan analisis regresi berganda. Perhitungan dilakukan dengan bantuan program SPSS versi 23 for windows dan diperoleh hasil sebagai berikut:

Tabel 4. Hasil Analisis Regresi Berganda

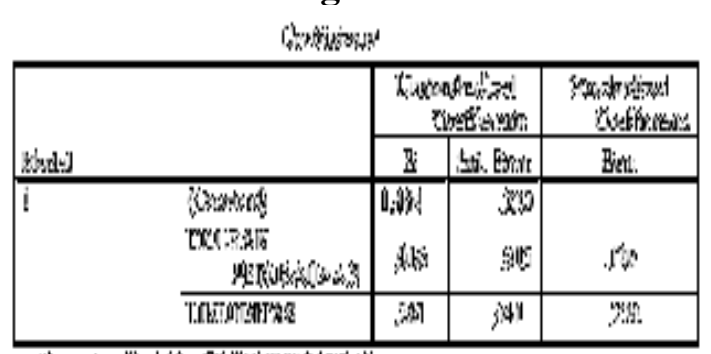

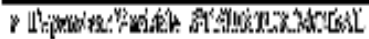

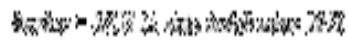

Dari tabel di atas dapat diketahui bahwa persamaan regresi berganda pada penelitian ini adalah sebagai berikut :

$$
Y=1,404+0,016 X 1+0,261 X 2
$$

Dari persamaan regresi tersebut, dapat diketahui bahwa koefisien intercept (a) dari persamaan di atas adalah sebesar 1,404 yang mengandung pengertian bahwa pada saat tingkat ukuran perusahaan (X1), dan likuiditas (X2) tetap, maka tingkat perolehan struktur modal (Y) adalah sebesar 1,404. Dari persamaan di atas juga dapat diketahui bahwa jika ukuran perusahaan (X1) naik sebesar $1 \%$ sedang variabel lain dianggap konstan maka tingkat struktur modal (Y) akan naik sebesar 0,016. Jika likuiditas (X2) naik 1\% sedang variabel lain dianggap konstan, maka tingkat struktur modal (Y) akan naik sebesar 0,261. Sehingga hasil analisis regresi linear berganda memberikan gambaran bahwa variabel ukuran perusahaan, dan likuiditas akan memiliki hubungan yang positif terhadap variabel struktur modal.

Uji statistik $t$ pada dasarnya menunjukkan seberapa jauh pengaruh satu variabel bebas (independent) secara parsial atau individual dalam mempengaruhi variabel tidak bebas (dependent).

Tabel 5. Hasil Uji t (Parsial)

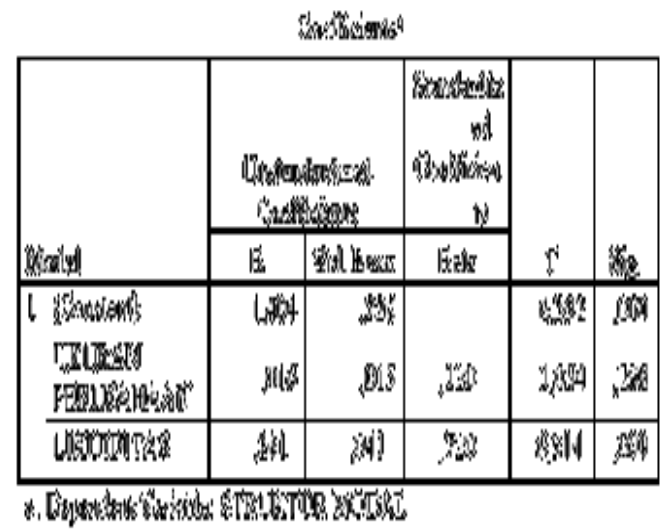

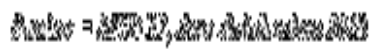

\section{1) Pengaruh Ukuran Perusahaan} (X1) terhadap Struktur Modal (Y)

Berdasarkan tabel diatas dimana nilai $\mathrm{t}$ hit untuk variabel ukuran perusahaan sebesar 1,054 dan tidak signifikan pada tingkat kepercayaan $\quad(a=0,05), \quad$ nilai signifikan yang diperoleh sebesar 
0,298 lebih besar dari 0,05. Nilai t tab dengan $\mathrm{a}=0,05$ dan derajat bebas $=42-1-1=40$ maka diperoleh nilai t tab 2,021. Oleh karna itu nilai thit untuk koofisien variabel ukuran perusahaan sebesar 1,054 lebih kecil dari t tab sebesar 2,021, maka pada tingkat kekeliruan $5 \% \mathrm{Ho}_{1}$ diterima dan $\mathrm{H} a_{1}$ ditolak. Artinya variabel ukuran perusahaan (X1) tidak berpengaruh dan tidak signifikan terhadap struktur modal (Y).

\section{2) Pengaruh Likuiditas (X2)} terhadap Struktur Modal(Y)

Berdasarkan tabel diatas dimana nilai t hit untuk variabel likuiditas sebesar 6,314 dan tidak signifikan pada tingkat kepercayaan $(a=0,05)$, nilai signifikan yang diperoleh sebesar 0,000 lebih kecil dari 0,05 . Nilai $\mathrm{t} t a b$ dengan $\mathrm{a}=$ 0,05 dan derajat bebas $=42-1-1=$ 40 maka diperoleh nilai $\mathrm{t} t a b$ 2,021. Oleh karna itu nilai t hit untuk koofisien variabel likuiditas sebesar 6,314 lebih besar dari t tab sebesar 2,021, maka pada tingkat kekeliruan $5 \% \mathrm{Ho}_{2}$ ditolak dan $\mathrm{Ha}_{2}$ diterima. Artinya variabel likuiditas (X2) berpengaruh positif dan signifikan terhadap struktur modal (Y).

Uji $F$ statistik digunakan untuk membuktikan hipotesis yang menyatakan ukuran perusahaan dan likuiditas terhadap struktur modal. Hasil pengujian dapat dilihat pada tabel berikut dengan tingkat signifikansi 5\% $(\alpha=0.05)$ :

Tabel 6. Hasil Uji F (Simultan)

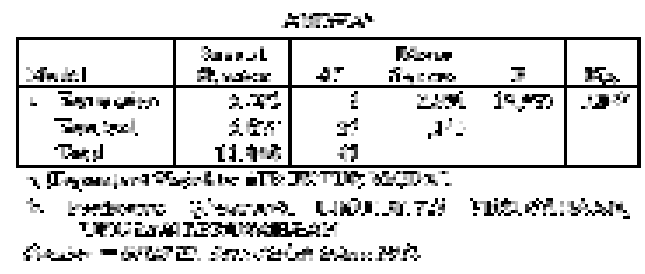

Berdasarkan tabel diatas dimana nilai $\mathrm{F}$ hit sebesar 19,933 dengan nilai signifikan 0,000 dan dari nilai $\mathrm{F}$ tab pada tingkat kepercayaan $95 \%$ dan derajat bebas $(2: 42)$ yang diperoleh dari $(\mathrm{k}: \mathrm{n}-\mathrm{k}-1)(2: 42-2-1=39)$ maka diperoleh nilai $\mathrm{F} t a b=3,238$. Oleh karna itu nilai $F$ hit 19,933 lebih besar dibanding nilai $\mathrm{F}$ tab 3,238 dengan tingkat kepercayaan $95 \%$ dan derajat kekeliruan 5\% $(\mathrm{a}=0,05) \mathrm{Ho}_{3}$ ditolak dan $\mathrm{H}_{3}$ diterima. Artinya variabel ukuran perusahaan (X1) dan likuiditas (X2) secara bersama-sama berpengaruh positif dan signifikan terhadap struktur modal (Y).

Dalam uji regresi linear berganda ini, dianalisis pula besarnya koefisien determinasi (R2) secara keseluruhan. Koefisien determinasi menunjukkan seberapa besar persentase variabel independen ukuran perusahaan dan likuiditas secara bersama-sama menerangkan variasi variabel dependen struktur modal. Dari hasil olah data menunjukkan hasil koefisien determinasi sebagai berikut:

\section{Tabel 7. Hasil Koofisien Determinasi}

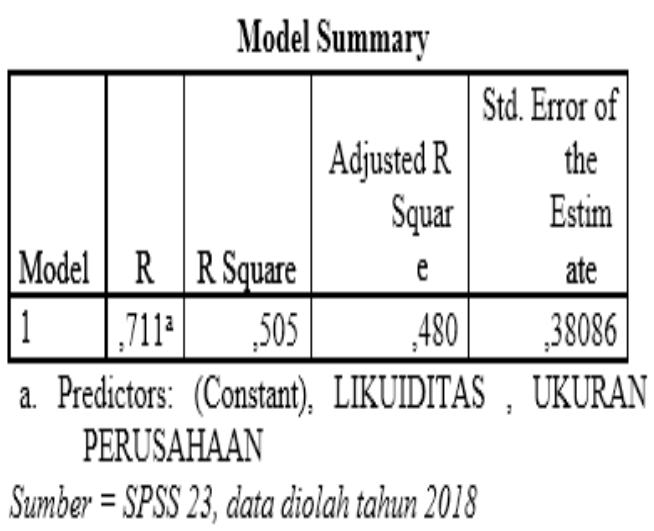

Dari hasil tabel diatas koefisen determinasi diatas, menunjukkan bahwa koefisien determinasi (R2) sebesar 0,505 atau 50,5\%. Jadi dapat dikatakan bahwa $50,5 \%$ perubahan struktur modal disebabkan oleh perubahan ukuran 
perusahaan dan likuiditas, sedangkan $49,5 \%$ sisanya disebabkan oleh variabel lain yang tidak diteliti dalam penelitian ini.

\section{INTERPRETASI HASIL PENELITIAN}

a. Pengaruh Ukuran Perusahaan secara parsial terhadap Struktur Modal (Studi pada Perusahaan Manufaktur Sektor Makanan Dan Minuman Di Bursa Efek Indonesia).

Hipotesis pertama yang diajukan secara parsial yaitu $\mathrm{H}_{1}$ : ukuran pesahaan berpengaruh positif dan signifikan terhadap struktur modal. Hasil statistik yang telah dilakukan memiliki nilai nilai $\mathrm{t}$ hit sebesar 1,054 lebih besar dari nilai t tab 2,021 dan nilai signifikan yang dihasilkan yakni 0,298 lebih besar dari nilai 0,05 maka $\mathrm{Ho}_{1}$ diterima dan $\mathrm{H} a_{1}$ ditolak. Dengan demikian hipotesis yang diajukan diterima ini terbukti dari hipotesis yang dihasilkan menunjukkan ukuran perusahaan berpengaruh positif dan tidak signifikan terhadap struktur modal (Studi pada Perusahaan Manufaktur Sektor Makanan Dan Minuman Di Bursa Efek Indonesia). Artinya Ukuran perusahaan menggambarkan seberapabesar kecilnya suatu perusahaan yang dilihat dari jumlah aset yang dimiliki ataupun penjualan bersih. Ukuran perusahaan dapat digunakan dalam menilai keberhasilan manajemen dalam mengelola keuangan perusahaan, karena dengan semakin banyaknya aset yang dimiliki perusahaan maka akan semakin banyak arus kas yang akan dikelola perusahaan yang akan digunakan untuk menjalankan kegiatan perusahaan maupun akan dibagikan kepada pemegang saham dalam bentuk dividen.

Semakin kecil ukuran sebuah perusahaan mengindikasikan semakin kecil pula jumlah aset yang dimiliki, semakin banyak pula hutang yang digunakan sebagai sumber pendanaan perusahaan. Besar kecilnya suatu perusahaan sangat mempenganuhi keputusan penggunaan utang dalam struktur modal perusahaan, terutama terkait dengan kemampuan perusahaan dalam memperoleh pinjaman. Perusahaan besar akan lebih mudah dalam memasuki pasar modal, perusahaan besar juga memiliki usaha yang lebih terdiversifikasi sehingga perusahaan besar lebih diperhatikan oleh investor maupun kreditor, perusahaan besar juga dianggap mempunyai kemampuan pengembalian pinjaman yang baik sehingga akan lebih mudah untuk memperoleh pinjaman.

Ukuran perusahaan yang tinggi akan meningkatkan struktur modal. Hal ini di indikasikan bahwa jumlah aset dalam perusahaan akan juga meningkat dimana meningkatnya jumlah aset akan mempengaruhi struktur modal dalam perusahaan dan perusahaan yang besar mampu menciptakan investor tertarik untuk menanamkan saham pada perusahaan tersebut. Penelitian ini juga didukung oleh Ni Made Noviana Chintya Devi, Ni Luh Gede Erni Sulindawati Dan Made Arie Wahyuni (2017) hasil penelitiannya menunjukkan ukuran perusahaan berpengaruh positif dan tidak signifikan terhadap struktur modal.

\section{b. Pengaruh Likuiditas secara parsial terhadap Struktur Modal (Studi pada Perusahaan Manufaktur Sektor Makanan Dan Minuman Di Bursa Efek Indonesia).}

Hipotesis kedua yang diajukan secara parsial yaitu $\mathrm{H}_{2}$ : likuiditas berpengaruh positif dan signifikan terhadap struktur modal. Hasil statistik yang telah dilakukan memiliki nilai nilai t hit sebesar 6,314 lebih besar dari nilai t tab 2,021 dan nilai signifikan yang dihasilkan yakni 0,000 lebih kecil dari nilai 0,05 maka $\mathrm{Ho}_{2}$ ditolak dan $\mathrm{Ha}{ }_{2}$ diterima. Dengan demikian hipotesis yang diajukan diterima ini terbukti dari hipotesis yang dihasilkan menunjukkan likuiditas berpengaruh positif dan signifikan terhadap struktur modal 
(Studi pada Perusahaan Manufaktur Sektor Makanan Dan Minuman Di Bursa Efek Indonesia). Artinya semakin besar likuiditas maka semakin besar pula struktur modal dan jika semakin kecil likuiditas maka semakin kecil pula struktur modal.

Semakin tinggi kemampuan perusahaan dalam mengembalikan kewajibankewajiban jangka pendeknya maka semakin likuiditas perusahaan tersebut sehingga kepercayaan dari kreditur meningkat dan mempermudah perusahaan memperoleh utang jangka panjangnya. Perusahaan yang memiliki likuiditas yang tinggi berarti perusahaan memiliki internal financing yang akan cukup digunakan untuk membayar kewajibannya sehingga struktur modal juga berkurang. Penelitian ini juga didukung oleh Luthfillah Zul Fahmi dan Kurnia (2017) hasil penelitiannya menunjukkan likuiditas berpengaruh signifikan dan positif terhadap struktur modal.

\section{c. Pengaruh Ukuran Perusahaan dan Likuiditas secara bersama-sama terhadap Struktur Modal (Studi pada Perusahaan Manufaktur Sektor Makanan Dan Minuman Di Bursa Efek Indonesia).}

Hipotesis ketiga yang diajukan secara simultan adalah $\mathrm{H}_{3}$ : ukuran perusahaan dan likuiditas secara bersama-sama berpengaruh positif dan signifikan terhadap struktur modal. Hasil statistik yang telah dilakukan memiliki nilai $\mathrm{F}$ hit 19,933 lebih besar dibanding nilai $\mathrm{F}$ tab 3,238 dan nilai signifikan yang dihasilkan yakni 0,000 lebih kecil dari nilai 0,05 maka $\mathrm{Ho}_{3}$ ditolak dan $\mathrm{Ha}_{3}$ diterima. Dengan demikian hipotesis yang diajukan diterima ini terbukti dari hipotesis yang dihasilkanmenunjukkanukuran perusahaan dan likuiditas secara bersama-sama berpengaruh positif dan signifikan terhadap struktur modal (Studi pada Perusahaan Manufaktur Sektor Makanan Dan Minuman Di Bursa Efek Indonesia). Artinya semakin tinggi ukuran perusahaan mengindikasikan semakin besar pula jumlah aset yang dimiliki, semakin banyak pula hutang yang digunakan sebagai sumber pendanaan perusahaan. Sehingga meningkatnya likuditas perusahaan akan membantu perusahaan untuk membayar utangnya. karena perusahaan dengan tingkat likuiditas yang tinggi mempunyai dana internal yang besar sehingga perusahaan tersebut akan lebih menggunakan dana internalnya terlebih dahulu untuk membiayai investasi sebelum menggunakan pembiayaan eksternal melalui hutang. Pada umumnya suatu Likuiditas yang rendah lebih banyak mengandung risiko daripada suatu Likuiditas yang tinggi, tetapi kadang suatu current ratio yang rendah menunjukkan pimpinan perusahaan menggunakan aktiva lancar dengan efektif.

Besar kecilnya suatu perusahaan sangat mempengaruhi keputusan penggunaan utang dalam struktur modal perusahaan, terutama terkait dengan kemampuan perusahaan dalam memperoleh pinjaman. Perusahaan besar akan lebih mudah dalam memasuki pasar modal, perusahaan besar juga memiliki usaha yang lebih terdiversifikasi sehingga perusahaan besar lebih diperhatikan oleh investor maupun kreditor, perusahaan besar juga dianggap mempunyai kemampuan pengembalian pinjaman yang baik sehingga akan lebih mudah untuk memperoleh pinjaman.

\section{KESIMPULAN}

Berdasarkan hasil penelitian di tarik sebuah kesimpulan sebaga berikut:

1. Uji t (parsial) menunjukkan ukuran perusahaan (X1) tidak berpengaruh dan tidak signifikan terhadap struktur modal (Y) (Studi pada Perusahaan Manufaktur Sektor Makanan Dan 
Minuman Di Bursa Efek Indonesia).

Bisnis dan Akuntansi, 13(1), 3956.

2. Uji $\mathrm{t}$ (parsial) menunjukkan likuiditas (X2) berpengaruh positif dan signifikan terhadap struktur modal (Y) (Studi pada Perusahaan Manufaktur Sektor Makanan Dan Minuman Di Bursa Efek Indonesia).

3. Uji F (Simultan) menunjukkan ukuran perusahaan (X1) dan likuiditas (X2) berpengaruh positif dan signifikan terhadap struktur modal (Y) (Studi pada Perusahaan Manufaktur Sektor Makanan Dan Minuman Di BursaEfek Indonesia).

\section{SARAN}

Berdasarkan hasil penelitian, saran yang dapat diberikan dalam penelitian ini adalah :

1. Dalam pengambilan sampel disarankan lebih memperbanyak populasinya, sehingga jumlah sampel lebih banyak, semakin banyak sampel yang diolah akan mempengaruhi hasil statistik yang positif dan signifikan.

2. Bagi peneliti selanjutnya terkait dengan struktur modal lebih mengembangkan lagi variabel independennya dalam mempengaruhi struktur modal.

3. Untuk peneliti selanjutnya yang akan mengambil judul ini untuk penulisan skripsinya, agar melakukan penelitian dengan menggunakan data berupa laporan keuangan dari perusahaan yang berbeda jenis, seperti jasa, perusahaan perbankan dan perusahaan di bidang industri.

\section{DAFTAR PUSTAKA}

Seftianne dan Ratih Handayani. (2011). Faktor-faktor yang Mempengaruhi Struktur Modal Pada Perusahaan Publik Sektor Manufaktur.Jurnal

Agnes Sawir. (2004). Analisis Kinerja Keuangan dan Perencanaan KeuanganPerusahaan, Jakarta : PT. Gramedia Pustaka Utama

Hani Syafrida, (2015). Teknik Analisa Laporan Keuangan. Medan: UMSU PRESS

Ozkan, Aydin. (2001).Determinants of Capital Structure and Adjustment to Long Run. Journal of Business Finance and Accounting. January-March.p:175196.

Kusumawati, (2004), Pengaruh Kinerja Keuangan Terhadap Struktur Modal pada Perusahaan Real Estate dan Propertyyang Listed di BEI Periode Tahun 2002-2003. Skripsi Universitas Diponegoro: Semarang.

Vina Ratna Furi, Saifudin, (2012), Faktor-faktor yang Mempengaruhi Struktur Modal (Studi Empiris pada Perusahaan Manufaktur yang Terdaftar di BEI Tahun 2009-2010), JURAKSI, ISSN: 2301-9328 Vol.1 No.2 Februari, Semarang.

I Made Sudana. (2011). Manajemen Keuangan Perusahaan. Erlangga, Jakarta.

Luthfillah, Z.M dan Kurnia, (2017), Pengaruh Struktur Aktiva, Ukuran Perusahaan, Dan Likuiditas Terhadap Struktur Modal".Volume 6, Nomor 2, Februari 2017.

Stenyverens, J.D Lasut., Paulina, Van Rate., dan Michael, Ch. Raintung. (2018). Pengaruh Ukuran Perusahaan, Profitabilitas, dan Likuiditas terhadap Struktur 
Modal pada perusahaan otomotif yang terdaftar di Bursa Efek Indonesia periode 2012-2015. Universitas Sam Ratulangi Manado. Manado : Vol.6 No.1, Hal : 11-20.

Ni Luh Gede Erni Sulindawati, Ni Made noviana chintya Devi., Made Arie Wahyuni., (2017).,: Pengaruh
Struktur Aktiva, Profitabilitas,

Ukuran Perusahaan, Likuiditas, dan Kepemilikan Manajerial terhadap Struktur Modal, eJournal S1 Ak Universitas Pendidikan Ganesha Jurusan Akuntansi Program S1 Vol. 7 No.1 hal 1-12. 